\title{
The Optimism as Self-actualization Fulfillment in the Novel Pollyanna
}

\author{
Azni Rizka Anandari Antung \\ Balikpapan University \\ aznirizkaanandariariza@gmail.com \\ Siti Hafsah \\ Balikpapan University \\ siti.hafsah@uniba-bpn.ac.id \\ Ulum Janah \\ Balikpapan University \\ ulum.janah@uniba-bpn.ac.id
}

\begin{abstract}
:
This research aims to analyze the role of optimism towards the self-actualization fulfilment in the novel Pollyanna by Eleanor H.Porter. The objectives of this research are to identify the reflection of optimism obtained. The theory use in this research is the optimism approach and the hierarcy of needs by Abraham Maslow. This research uses the qualitative descriptive method in analysis of the novel. The researcher found the reflection of optimism and the basic need obtain in order to fulfil the self-actualization. There are categorized the existence, help, happiness and joyfulness which as the optimism reflection that became impact in self-actualization fulfilment of the main character.
\end{abstract}

Keywords: optimism, self-actualization, Pollyanna

\section{INTRODUCTION}

In a human life, there are many people with different mind and different goals in their life. Every human chooses and decides what they want and how their life will be. Life is like an option, choose a good thing and be a kind person it will make a positive life; and choose a bad thing, it will give the negative effect. The positive mind of human rise from the motivation inside itself. The motivation means built from the self-fulfillment as the part of human need. Therefore, human must fulfill the needs in the life as human being. One of the 
human needs is self-actualization. It means, people as human have the actualize of their self to do all the potential in the life in achieving something. The actualization in human being is the way people achieving something to make it become real in their life. The actualize is the way that human do the best things as their being as human with all potentials hey have. In actualization supported by self-confidence as the trigger. The kind of self-confidence is the optimistic personality. The optimist personality motivate person become positive and be the optimism in the life. According to Robert, positive thinking and negative thinking are both filtered through our belief system. Right thinking comes from being aware of the truth or the reality of any situation. (Robert,2005 p.12)

In human being in the way people belief on good things and hoping the good life is the kind of optimism. It can be the trigger of positive life and mind to make healthier and happiness life. Optimism be able be as a magnet when people be and positive believe, every positive thing will come. Therefore, it can affect the good personality and good result in human life. According to Scheier, optimism was inversely correlated with focus on emotion and emotional expression, and with disengagement from the goal. (Scheier ,1985 p.241)

Therefore, the optimism also can be seen in the literary works. Literary works itself is a creative and innovative of a writing. In the literary works contained imaginations and a fact in real life. It also has a genre; its genre of literary works are prose, poetry and drama. Prose is a form of language that has no formal metrical structure. Novel is the one kind of prose. Novel is the one kind of prose. It invented prose narrative of considerable length and a certain complexity that deals imaginatively with human experience, usually through a connected sequence of events involving a group of persons in a specific setting. According to Sumardjo, novel is a story with the prose form in long shape, this long shape means the story including the complex plot, many character and various setting. (Sumardjo,1998 p. 29)

The literary works give the representation of optimism from the characters and the story. One of the literary works that shows the optimism reflection is the novel Pollyanna. Pollyanna is the object of this research. It is a 1913 novel by American author Eleanor H. Porter, considered a classic of children's literature. In this research will use the novel Pollyanna as the object. This optimism characteristic that is shown by Pollyana is very interested to examine. Those build her optimism that affect to her self-actualization. Selfactualization is the kind of high level in human being.

\section{LITERATURE REVIEW}

\section{Optimism}

Optimism is the part of human being on goal achievement in the life. Martin Seligman was the part of positive psychology expert that explain and has a theory of positive mind. Seligman defines optimism as a belief that bad events are only temporary, do not fully affect all activity, and not entirely due to self-carelessness but it can because of a situation, fate, or someone else. When experiencing an event that is fun, optimistic individuals will be convinced that it will lasts long, affects all activities and is caused by self alone. 
According to the Seligman, in human optimism there are aspects and factors in order to obtain it. The permanence aspect has the meaning that someone responds to something bad or good event in permanent, but for optimistic individuals they will see bad events will be temporary in their life. The aspect of pervasiveness in optimistic individuals will give reason for each failure and explained the cause. The personalization aspect explains every cause of a failure comes from internal (individual self) or external (others).

The factors of optimism can be obtained from social support, it will make the person feels needed by other people in their life. Self-confidence is the kind of optimism that supports the self to be confident and be more optimist of what they have in their self. The selfesteem is the factor of the optimism, that people with self-esteem to be able to respect of their self and will do everything best and learn from the failure.

\section{Hierarchy of Need}

Hierarchy of Needs is the theory by Abraham Maslow. He divided into 5 steps in human needs. It relates to each other in order to fulfill the human basic needs.

\section{Physiological Need}

Physiological Need is the most basic human. According to Maslow. These needs include food, water, oxygen, sex, and all the physical elements that support organism life. When these needs are not met, humans will live with a narrow purpose to meet these basic needs. In short, this need is very basic.

\section{The Safety Need}

The safety needs is the part of need includes a physical and emotional sense of safety. Humans need stability, protection, and freedom from such things as war or anxiety. The need for law, order and structure is included in this need.

\section{Love and Belonging Need}

Love and belonging need is the need for affection and acceptance as emotional need that included the need to have friends, spouses, or family. Humans have a need to fit in with one another and to have social identity. Maslow suggests that the need also includes several aspects of human contact and the need to give and receive love. (Maslow, 1970, p.249)

\section{Esteem Need}

Esteem need is the need that includes self-esteem, confidence, self-competition, and a feeling of being appreciated by others. Maslow divides this need into two levels. The selfreputation is the one's perception of prestige, achievement, and fame in the eyes of others. Then the self-esteem as useful as a person's confidence.

\section{Self-actualization Need}

Self-actualization need is the final step in human need. This is the unique need that there is not automatically achieved when individuals have met the need for recognition. Those who have filled this need become complete human beings. They naturally behave in a way that contributes to their potential. Those who have successfully actualized are no longer 
dependent on meeting affective needs, they have developed into individuals free from lower levels of need.

\section{RESEARCH METHODOLOGY}

This research uses qualitative research. The characteristics of qualitative research are lies in the purpose of qualitative research, which is to understand the meaning attributed to individual's experiences. The data emerges from a qualitative research are descriptive. In this research use descriptive qualitative as procedure by identifying the role of optimism as self-actualization fulfillment from the main character in Pollyanna. The researcher uses psychology of literature approach. In psychology of literature there's hierarchy of need by Abraham Maslow that be able to support the self-actualization. It reflected from the human basic needs by the main character. The reflection can obtain the optimism as the personality built by the actualization from the main character. The primary source of data of this research is the quotation of conversation in the Pollyanna. Pollyanna wrote by Eleanor $\mathrm{H}$. Porter, originally published 1913, and first publish in Indonesia by Gramedia Pustaka Utama. The secondary data of this research is from various journal and books to support the data analysis. During data collection procedures, First step during data analysis is read the novel repeatedly, to identify the quotation of the conversation that contain the optimism reflection towards motivation approach and optimism of the characters conversations between the main character in the novel, collect the data and grouped according to the conflict and approach and analyze the quotation with the form of self-actualization fulfillment.

\section{FINDINGS}

Pollyanna as the main character in the novel has a positive personality, it makes her can be happy and love herself. She has positive mind and always be grateful of everything; she plays "glad" game in all her life. However, from the human of need, the optimism became the trigger of her self-actualization. Pollyanna's optimism reflection as the factor of selfactualization found in the novel are existence, helping each other, sharing the happiness and joyfulness. The existence as the factor in optimism of main character is humble and friendly and can share the happiness with make a friend with strangers. The main character sharing the happiness by playing the game with her father. The joyfulness of the main character is from the glad game that change everyone's life to be more grateful and the main character is also happier than before.

\section{DISCUSSION}

This part, the researcher explains about the self-actualization from the process of needs fulfillment. The self-actualization is the final step of hierarchy of need form by Maslow. This step of needs must be fulfilled by other needs on the basic steps as explained on the section before. In this research the 4 steps before the self-actualization itself already 
fulfilled by the excerpt that found in the novel. The main character, Pollyanna. achieves the needs by fulfilled her physiological, safety, love and esteem of herself through other characters and her own self until she reaches the final step of the needs; self-actualization.

The self-actualization in this section will be explained from the excerpts found in the novel and divided into four kinds. Those kinds will describe the trigger of how Pollyanna's selfactualization can be fulfilled and affected her optimism.

\section{Existence}

This section will explain about the existence of the main character, Pollyanna. The existence in this section means about the awareness and the care about the Pollyanna's figure by the other characters in the novel. Pollyanna's role become the trigger of other characters to obtain her own self-actualization. The main character has the important role, as the effect of herself. In other condition, the awareness of other characters make Pollyanna's existence. This will be explained in following excerpts.

'I-I came to inquire for the little girl,' she stammered.

"You are very kind. She is about the same. How is your mother?' rejoined Miss Polly, wearily.

"That is what I came to tell you-that is, to ask you to tell Miss Pollyanna," hurried on the girl, breathlessly and incoherently. "We think it's - so awful - so perfectly awful that the little thing can't ever walk again; and after all she's done for us, too-for mother, you know, teaching her to play the game, and all that. And when we heard how now she couldn't play it herself_-poor little dear! I'm sure I don't see how she CAN, either, in her condition!- but when we remembered all the things she'd said to us, we thought if she could only know what she HAD done for us, that it would HELP, you know, in her own case, about the game, because she could be glad-that is, a little glad-" Milly stopped helplessly, and seemed to be waiting for Miss Polly to speak. (Pollyanna, p.228)

Pollyanna has many relations with other people around her. She loves meeting people and never hesitates to make friends. The excerpt shows a woman comes to Pollyanna. She comes because she remembers Pollyanna. Milly comes when Pollyanna gets into an accident, and she is really sad about it. She wants to help Pollyanna with the game. In this condition, Pollyanna's existence is obtained from other character's care and her importance in someone else's life.

"For a moment there was silence. Then a low voice from the bed said unsteadily: 'Perhaps; but I'm thinking that the very finest prism of them all is yourself, Pollyanna." (Polyanna, p.159)

The excerpt shows the conversation happened between Mr. Peddleton and Pollyanna. The excerpt shows how Mr. Peddleton's care to Pollyanna. He always remembers about Pollyanna since she always greets him until the two become friends. According to the 
excerpt, Mr. Peddleton admits her as his finest prism, it means he treats her as a special person for him. Therefore, as Mr. Peddleton treats Pollyanna as fine and always remember her, it becomes the kind of Pollyanna existence through Mr.Peddleton.

\section{Helping Each Other}

The main character's role in helping other people will be explained. Pollyanna has a caring and loving personality in herself. She loves to help people, it is her expression of love to everyone. Based on the needs of self-actualization, it can be increased by internal factors, one of them is the initiative one person. It can be shown from Pollyanna through the way she helps other characters in the novel.

'Oh, well, you know, I was pretty cross with you, I'm afraid, both the other day when you so kindly brought me the jelly, and that time when you found me with the broken leg at first. By the way, too, I don't think I've ever thanked you for that. Now I'm sure that even you would admit that you were very forgiving to come and see me, after such ungrateful treatment as that!" (Pollyanna, p.145)

Mr. Peddleton is one of Pollyanna's friends. One time, Pollyanna finds him with a broken leg when he gets into an accident. Pollyanna tries to help him. The days after, Mr. Peddleton gets closer with Pollyanna because of her help. He also thanks her for the jelly she brings him that day. The excerpt shows the relationship between Mr. Peddleton with Pollyana becomes closer because of Pollyanna's action to help him. With her help to others and how it affects in tighten the relationship between other people it can be shown as selfactualization.

'Will you tell her, please, that - that I've put on THIS,' she said, just touching the blue bow at her throat. Then, at Miss Polly's ill-concealed look of surprise, she added: 'The little girl has been trying for so long to make me wear-some color, that I thought she'd be-glad to know I'd begun. She said that Freddy would be so glad to see it, if I would. You know Freddy's ALL I have now. The others have all-'Mrs. Benton shook her head and turned away. 'If you'll just tell Pollyanna-SHE'LL understand.' And the door closed after her.” (Pollyanna, p.231)

The excerpt above is the quotation from a woman; Mrs. Benton. According to the story, she is the saddest women in the town. Mrs. Benton pays a visit to Mrs. Polly because she knows about Pollyanna, that she is in a bad condition. One time, Pollyanna once helps her in choosing the color of the clothes she wears. Pollyanna shares and gives her advice and makes Mrs. Benton's life look colorful. From the excerpt, the saddest women in the town can change her life since met Pollyanna, until in the one bad condition, she keeps remembering and being sad about her condition. In this situation, with Pollyanna's help can affect the other's character life in make it better. 


\section{Sharing the Happiness}

This section will describe about Pollyanna's game from the excerpt. The main character has the game that is taught by her father. The game is named "Glad" game. Pollyanna always plays it in her life; no matter how hard, but it worked to make her grateful about her life. The game has changed her life, to make her always looks into other side or perspective and think positively. Pollyanna as the friendly girl in the novel, she never hesitates to share the game to everyone she meets. The "Glad" game can affect other character in their way. In this section will describe the excerpt that contain the role of Pollyanna in the way she shares the "Glad" game. This can be seen in the following excerpts.

I know; but you're HELPING it—don't you see? - and of course you're glad to help it! And so that makes you the gladdest of any of us, all the time.' The doctor's eyes filled with sudden hot tears.

The doctor's life was a singularly lonely one. He had no wife and no home save his two-room office in a boarding house. His profession was very dear to him. Looking now into Pollyanna's shining eyes, he felt as if a loving hand had been suddenly laid on his head in blessing. He knew, too, that never again would a long day's work or a long night's weariness be quite without that new-found exaltation that had come to him through Pollyanna's eyes. (Pollyanna, pp.132-133)

The "Glad" game is shared by Pollyanna to everyone, even to a stranger. According to the excerpt above, Pollyanna met Dr. Chilton and they become friend. Pollyanna understands how the doctor works all day, to help other people who in a sick until they in better condition. Pollyanna tells her advice to the doctor, saying that he should be glad because he has helped everyone. From the excerpt, Dr. Chilton was very touched because of Pollyanna's words. He becomes grateful of his condition even when he is in a bad situation. Pollyanna shares about gladness to Dr. Chilton and the game makes him feels grateful.

"Oh, but that was before you taught me to play that wonderful game of yours. Now I'm glad to be waited on, hand and foot! Never mind, I'll be on my own two feet yet, one of these days; then I'll see who steps around,' he finished, picking up one of the crutches at his side and shaking it playfully at the little girl. They were sitting in the great library to-day." (Pollyanna, p.161)

Mr. Peddleton is the other character that learns the game from Pollyanna. The excerpt above shows that Mr. Peddleton says that the game he plays is wonderful. Pollyanna visits Mr. Peddleton after he gets into an accident, Pollyanna tells him about the "glad" game. Based on the excerpt, Mr. Peddleton admits that he feels glad after playing the game, and he can feel more grateful even with his condition after the accident.

\section{Joyfulness}

Pollyanna shares her "Glad" game to everyone in town. It makes all folks and everyone who ever met Pollyanna knows and remembers her. She shares the important and 
meaningful thing that can impact other characters' life. The main character is the first one to play the game before she shares it to anyone else. Pollyanna always plays the "Glad" game daily. This section will describe the excerpt that shows the expression and the improvement of Pollyanna's happiness towards the game that she already shares to all people in the novel.

“There, there, don't,' choked her aunt. 'Perhaps you'll drive up sometime. But listen! I haven't told you, yet, all that Mrs. Payson said. She wanted me to tell you that they-they were going to stay together and to play the game, just as you wanted them to.' Pollyanna smiled through tear-wet eyes.

'Did they? Did they, really? Oh, I am glad of that!'

'Yes, she said she hoped you'd be. That's why she told you, to make you-GLAD, Pollyanna.' (Pollyanna, p. 240)

Mrs.Polly tells Pollyanna about the message that is given by Mrs. Payson. Mrs. Payson knows about the game. At the time when Pollyanna cannot walk, Mrs. Payson gives her care by playing the "Glad" game with Pollyanna. She helps Pollyanna to get better and be grateful again.

"Pretty soon, they say, I shall go home. I wish I could walk all the way there. I do. I don't think I shall ever want to ride anywhere any more. It will be so good just to walk. Oh, I'm so glad! I'm glad for everything. Why, I'm glad now I lost my legs for a while, for you never, never know how perfectly lovely legs are till you haven't got them-that go, I mean.

I'm going to walk eight steps to-morrow. (Pollyanna, p.256)

The except above describes how Pollyanna feels about her condition. She is grateful about it. Even when she is in a bad condition, she still thinks and see the bright side about it. The excerpt shows that she can be grateful about anything and try not to regret things in her life.

Pollyanna as the main character in the novel has the form of positive things toward her life. In her ways to reach the positive life, she has to fulfill her basic needs. Pollyanna has fulfilled her needs and achieved the final steps; the self-actualization that already explained from the excerpts in sections before.

\section{CONCLUSION}

The basic needs of human have to fulfill in their life. Human needs are divided into steps; basic into final step. It means that each need must be fulfilled before moving to the next step. The role of optimism in this research limited to how the main character fulfill all the needs and reached the final steps of human needs, self-actualization. In order to achieve the self-actualization, the main character have fulfilled all the basic needs. The main character's self-actualization is obtained from the environment and people around her. The basic needs is fulfilled when the main character got all daily needs, safety, love, people around who make her known and loved. This research proves that the basic needs has 
important role in the way of achieving the self-actualization. The main character has a positive personality. It helps building the existence from within herself. From the data shown that the optimism became the trigger of better life and self-actualization in human being.

\section{References}

Anthony, R. (2005). Beyond Positive Thinking: Formerly "The advanced Formula for Total Success". Morgan James Publishing

Maslow, A. (1968). Toward a Psychology of Being; Second Edition. Van Nostrand Reinhold Company Inc.

Viking Press.

(1976) The Farther Reaches of Human Nature. United States of America: The

Porter, E. H. (2018) Pollyanna. Jakarta: Gramedia Pustaka Utama.

Scheier, M. F., \& Carver, C. S. (1985). Optimism, coping, and health: Assessment and implications of generalized outcome expectancies. Department of Psychology, Carnegie-Mellon University 4.3

Seligman, M. (1991) Learned Optimism. NY: Knopf. . (2002) Positive Psychology, Positive Prevention, Positive Therapy. Handbook of Positive Psychology. Oxford: Oxford University Press. . (2012) Flourish; A Visionary New Understanding of Happiness and Well-being. New York: Free Press.

Sumardjo, J. \& Saini, K. M. (1998) Apresiasi Kesusastraan. Jakarta: PT. Gramedia 